\title{
An empirical investigation of the audit expectation gap in Nigeria
}

\author{
Semiu Babatunde Adeyemi and Olayinka Marte Uadiale
}

Department of Accounting, University of Lagos, Lagos State, Nigeria.

Accepted 11 August, 2011

\begin{abstract}
The audit expectation gap (AEG) is denoted as the difference between what the public expects from an audit function and what the audit profession accepts the objective of auditing to be. The existence of an audit expectation gap is likely to be detrimental to the value of auditing and the well-being of the auditing profession as the contribution of auditing may not be fully recognized by society. This has stirred a number of professional and regulatory reforms aimed at protecting shareholders who rely on the financial statements for decision purposes. In spite of the existence of research pointing to the difference between what the public expects from audit and what the audit profession accepts as the objective of auditing, there appears to be paucity of research on how to address this issue in Nigeria. Therefore, this research investigates whether audit expectation gap exists in Nigeria and the perception of the users' group on its existence. Respondents view was also sought on how the gap could be narrowed. Three hypotheses were formulated and tested using the analysis of variance. The study reveals that an audit expectation gap exists in Nigeria, particularly on issues concerning auditor's responsibility. It was also observed that there are significant differences in the perception of respondent groups on the existence of the audit expectation gap in Nigeria. Therefore, the study suggests educating the public about the objects of an audit, auditors' role and responsibilities to narrow the audit expectation gap.
\end{abstract}

Key words: Audit, audit expectation gap, public expectation, Nigeria.

\section{INTRODUCTION}

There is concern that auditors and the public hold different beliefs about the auditors' duties and responsibilities, and the messages conveyed by audit reports; and also, that the existence of this expectation gap might cause the end users to eventually lose their trust in audit reports all-together. The existence of an audit expectation gap implies that the role senders (auditees and audit beneficiaries) are dissatisfied with the performance of auditors (Koh and Woo, 1998). In recent years, there has been sudden collapse of corporate institutions within and outside the country (for example Enron and Worldcom in USA; Cadbury, NAMPAK, Intercontinental Bank, Oceanic Bank and Fidelity Bank in Nigeria) and the subsequent implications of the reporting, auditors has

\footnotetext{
${ }^{*}$ Corresponding author. E-mail: sbaadeyemi@yahoo.co.uk. Tel:
} +234-8035071047. highlighted the audit expectation gap.

Best et al. (2001) claim that society's trust is the 'heartbeat of a profession'. Hence, if such trust disappears or is eroded in any way, the outcome is likely to involve skepticism and the depletion of value attributed to such profession. It can therefore be said that the auditing profession, which was once highly regarded and whose members were among the most credible professionals, has now become shrouded by mistrust and skepticism (Salehi, 2007). Apparently, public misperceptions are a major cause of the legal liability crisis facing the accounting profession (Godsell, 1992; Maccarrone, 1993; Porter and Gowthorpe, 2004; Lee et al., 2007). Given the significance of the expectation gap, it is not surprising therefore that a number of studies have shown concern for the expectations problem (Humphrey et al., 1993; Koh et al., 1998).

The term "audit expectation gap (AEG)" was first introduced to audit literature by Liggio (1974). He defines 
the $A E G$ as the difference between the levels of expected performance as envisioned by users of a financial statement and the independent accountant. Monroe and Woodcliff (1993) define the audit expectation gap as the difference in beliefs between auditors and the public about the duties and responsibilities assumed by auditors and the messages conveyed by audit reports. Jennings et al. (1993) on the use of audit decision aids to improve auditor adherence to a "standard", are of the opinion that the audit expectation gap is the difference between what the public expects from the auditing profession and what the profession actually provides. This definition is also advocated by Lowe (1994) in his research on the expectation gap in the legal system. Porter (1993) did an empirical study of the audit expectation-performance gap. He defines the expectation gap as the gap between society's expectations of auditors and auditors' performance, as perceived by society. It is seen to comprise two components: i) reasonableness gap (that is, the gap between what society expects auditors to achieve and what the auditors can reasonably be expected to accomplish); and ii) performance gap (that is, the gap between what society can reasonably expect auditors to accomplish and what auditors are perceived to achieve).

Despite the importance of the AEG to the auditing profession, there is paucity of research on how to address this issue in Nigeria. Therefore, this study seeks to empirically establish the perceptions of auditors, auditees (management and accountants) and audit beneficiaries (stockbrokers and investors), on the existence of audit expectation gap in Nigeria and how the gap could be narrowed.

\section{Aim and objectives of the study}

The aim of this study is to provide evidence on the existence of audit expectation gap in Nigeria, by investigating the perception of selected stakeholders. In order to achieve this aim, the study seeks to:

i. investigate the respondents' perceptions on the existence of audit expectation gap in Nigeria;

ii. examine the perceptions of respondent groups on the existing duties and responsibilities of auditors;

iii. investigate the extent of reliance on audit reports by the respondent groups for investment decision;

iv. highlight ways to reduce the expectation gap.

\section{Research questions}

The study is designed to provide answers to the following research questions in order to achieve the afore stated objectives:

i. To what extent does audit expectation gap exist in Nigeria? ii. To what extent do respondents' perception on the existing duties and responsibilities of auditors differ?

iii. To what extent do the respondent groups rely on audit report for investment decision?

iv. In what ways can the expectation gap be reduced?

\section{Research hypotheses}

The following null hypotheses were tested in order to provide answers to the aforementioned research questions:

$\mathrm{H}_{01}$ : There is no significant difference in the perception of respondent groups on the existence of audit expectation gap in Nigeria.

$\mathrm{H}_{02}$ : There is no significant difference in the perception of respondent groups on the existing duties and responsibilities of auditors.

$\mathrm{H}_{03}$ : There is no significant difference in the perception of respondent groups on the usefulness of audit report for investment decision.

Research question iv was not subjected to the formulation of hypotheses. Hence they were answered using descriptive statistics only.

\section{Significance of the study}

The auditing profession in Nigeria has been under intense pressure due to rising public expectations. This empirical investigation of the audit expectation gap is therefore a significant contribution to existing literature. Furthermore, the study provides evidence on the extent to which audit expectation gap exists in Nigeria and the perception of respondent groups on existing duties and responsibilities of auditors.

Dixon et al. (2006) investigated the expectation gap between auditors and financial statement users in Egypt. The study confirmed the existence of an expectation gap in the nature of the audit function, the perceived performance of auditors, their duties and role, their independence and the non-audit services. Hence, an empirical investigation of the audit expectation gap in Nigeria is an effort towards narrowing the gap and gaining investors' confidence in the auditing profession. The findings of this study would serve as reference point for further research works relating to the audit expectation gap in Nigeria.

\section{Scope of the study}

This study is motivated by the current state of the auditing profession in Nigeria as a result of recent financial scandals. Therefore, the perceptions of selected stakeholders were sought in providing answers to the questions raised in the study. For the purpose of this 
study, only the auditors' duties and responsibilities as defined by Schedule 6 of the Companies and Allied Matters Act (CAMA) 1990 and Section 359 - Matters to Be Expressly Stated in Auditor's Report were taken into consideration (that is, their duties as defined by other regulatory bodies were not considered). The focus of the research in terms of study groups includes external auditors, auditees (private accountants and management) and audit beneficiaries (stockbrokers and investors) in Lagos State.

\section{LITERATURE REVIEW}

\section{Overview of audit expectation gap}

The issue of "audit expectation gap (AEG)" has been very significant to the accounting profession since the mid 1970s and continues to be debated on until today (Liggio, 1974; Lee et al., 2010). In the 1970s and 1980s, massive corporate failures resulted in the accounting profession being severely criticized by the public. The audit expectation gap has become a topic of considerable interest world wide, for research in general, and in the advanced countries like the U.S (Frank et al., 2001), the U.K (Innes et al., 1997), Australia (Gay et al., 1997), Denmark (Hojskov, 1998), New Zealand (Porter, 1993), and Singapore (Best et al., 2001). This is due to the occurrence of series of corporate failures, financial scandals and audit failures in these advanced countries and their subsequent impact on other countries' audit profession. The major corporate financial irregularity and related fraud which occurred in Nigeria in recent times, such as is reported in relation to Wema Bank, NAMPAK, Finbank, Cadbury and Springbank have captured the attention of investors and regulators alike. The search for mechanisms to ensure reliable, high quality financial reporting has largely focused on narrowing the audit expectation gap. The auditing profession has been proactive in attempting to improve audit quality by issuing standards focused on discovery and independence. As a result, there has been a concerted effort to devise ways of enhancing auditors' independence (Corporate Governance Code of Nigeria, 2005).

The foundations for research in audit expectation gap were laid down in the seminar works of Lee (1970) and Beck (1974), who investigated the duties which auditors were expected to perform. These studies ascertain the auditors' and the public's view of the roles and responsibilities of auditors through the use of questionnaire surveys. Liggio (1974) visualized the changing role of auditors at the initial stages and pioneered the concept of audit expectation gap.

The AEG refers to the difference between what the public and other financial statement users perceive auditors' responsibilities to be and what auditors believe their responsibilities to entail (McEnroe and Martens,
2001). It is assumed that auditors and users of financial statements have a different perception of the term "external audit" (Beelde et al., 2005). Reiter and Williams (2000) are of the view that the expectation gap refers to the public's expectation that companies with "unqualified" audit opinion, hence a true and fair view of the financial statements, should be free of financial fraud and shortterm risks of business failure. These misconceptions of the public contribute to the legal liability crisis facing the accounting profession (Maccarone, 1993).

The term 'expectation gap' is commonly used to describe the situation whereby a difference in expectation exists between a group with a certain expertise and a group, which relies upon that expertise. The public perception of an auditor's responsibility differs from that of the profession and this difference is referred to as the expectation gap. The term has been used not only in the accounting literature, but also in other fields, for example, to describe the perceptions of the information systems industry relating to the academic preparation of graduates (Trauth et al., 1993); difference in expectations of advertising agencies and their clients with respect to campaign values (Murphy and Maynard, 1996); differences in relation to various issues associated with corporate environmental reporting on one hand and the clash between auditors and the public over preferred meanings of the nature, objectives and outcomes of an audit (Sikka et al., 1998).

\section{Theoretical framework}

Role theory provides a theoretical explanation for the existence of an audit expectation gap. Based on role theory, an auditor can be viewed as occupying a status or position as a profession in the social system. Due to the 'position' of a 'profession', auditors are required to comply with the prescriptions ascribed to them by the society. 'Failure to conform to the ascribed role or to meet role expectations creates the risk of social action to enforce conformity and to penalize nonconformity' (Davidson, 1975).

According to Davidson (1975), 'the role of the auditor is subject to the interactions of the normative expectations of the various interest groups in the society (that is, different role senders) having some direct or indirect relationship to the role position.' He noted that these different groups (for example, management, the securities and exchange commission, institutional investors, analysts, auditors, accountants, etc.) may hold varying expectations of the auditor and these expectations may change from time to time depending on the re-specification of their own role requirements and the interaction of other forces in the society. Hence, the auditors are placed in multi-role and multi expectation situations. For the purpose of the study, stock brokers, investors, private accountants and management were used as role senders 
of the auditors.

\section{Audit expectation gap: Empirical evidences}

Empirical studies on audit expectation gap are extensive in developed economies. These studies (Frank et al., 2001; Innes et al., 1997; Gay et al., 1997; Hojskov, 1998; Porter, 1993; Best et al., 2001) mostly use survey questionnaires to identify the nature of the gap or where the gaps are, impacts of the gap, and how to reduce the gap. Different respondents have been used in the literature to elicit their opinion, for example, auditors, lawyers and judges (Lowe, 1994), investors (Epstein and Gregor, 1994), shareholders (Beck, 1974), chartered accountants, financial directors, investment analysts, bankers and financial journalists (Humphrey et al., 1993; Porter, 1993), financial directors and users of corporate financial statement (Benau et al., 1993).

Low (1980) examined the expectation gap in Australia. The extent of auditors' detection and disclosure responsibilities concerning errors, irregularities and illegal acts as perceived by auditors and non-auditor groups was investigated. It was found that both groups differed significantly in their perceptions of the extent of auditors' detection and disclosure responsibilities, and that an expectation gap existed between the two groups.

Humphrey et al. (1993) examined the expectation gap by ascertaining the perceptions of individuals of audit expectations issues through the use of a questionnaire survey comprising a series of mini-cases. The respondents included chartered accountants in public practice, corporate finance directors, investment analysts, bank lending officers and financial journalists. The survey revealed a significant difference between auditors and the respondents (represented by some of the main participants in the company financial report process) in their views on the nature of auditing. The results confirmed that an audit expectation gap exists, specifically in areas such as the nature of the audit function and the perceived performance of auditors.

Mohamed and Muhamad-Sori (2002) revealed that the audit expectation gap exists in Malaysia. The existence of the gap is due to a number of contributing factors such as, uncertainties concerning the actual role of auditor; the satisfaction of clients with services provided by the auditors; and the audit firm's lack of independence and objectivity.

A more comprehensive study was conducted by Fadzly and Ahmad (2004) to examine the audit expectation gap among auditors and major users of financial statements: bankers, investors, and stockbrokers. The study focused on the positive view of the expectation gap, which compared auditors' and users' perceptions on the duties of auditors.

To complement the findings of Fadzly et al. (2004), Lee and Palaniappan (2006) and Lee et al. (2007) conducted a survey on audit expectation gap in Malaysia to examine whether an expectation gap existed in Malaysia among the auditors, auditees and audit beneficiaries in relation to auditors' duties. In addition, the study analyzed the nature of the gap using Porter's framework. The results proved the existence of an audit expectation gap in Malaysia.

Dixon et al. (2006) investigated the expectation gap between auditors and financial statement users in Egypt. The study confirmed the existence of an expectation gap in the nature of the audit function, the perceived performance of auditors, their duties and role, their independence and the non-audit services. In a more recent study, Lee et al. (2010) analyzed the nature of the audit expectation gap in Thailand using Porter's (1993) framework. The study revealed that the auditees and audit beneficiaries have an expectation of auditors' duties that is far in excess of that of the auditors themselves. Their results confirm those of the previous study by Boonyanet and Ongthammakul (2006) that the audit expectation gap exists in Thailand.

An empirical study of the audit expectation gap in a developing country like Nigeria is a step in the right direction, since most of the studies available on this issue are from the developed economies.

\section{Auditors' duties and responsibilities in Nigeria}

The Companies and Allied Matters Act (CAMA), CAP C20, LFN 2004 is the principal law which sets the tone for the incorporation and conduct of business in Nigeria. Section 357 of the Act requires that every company shall at each annual general meeting (AGM) appoint an auditor(s) to audit the financial statements of the company. The Act further requires that the audit must be performed by an approved company's auditor as defined under Section 358 of CAMA 1990. Under Section 360 (4) of the CAMA 1990, auditors are required to include in their report if any of the requirements of the Act have not been complied with in the accounts. Specifically, the Act states that it shall be the duty of the company's auditor, in preparing their report, to carry out such investigations as may enable them to form an opinion as to the following matters whether: (a) proper records have been kept and adequate returns received from branches not visited by him; and (b) the company's balance sheet and profit and loss accounts are in agreement with the accounting records and returns. The auditors' report shall state the matters set out in the Sixth Schedule to CAMA as follows:

(i) Basis of preparation of the entity's financial statements (that is, the financial statements have been prepared on the basis of the entity's accounting policies);

(ii) Respective responsibilities of the directors and the auditors;

(iii) Basis of the auditors' opinion;

(iv) Whether proper books of account have been kept;

(v) Compliance with the provisions of the Companies and 
Allied Matters Act, Cap. C20 LFN 2004;

(vi) Compliance with the statements of accounting standards issued by the Nigerian Accounting Standards Board (NASB).

The auditors are required to follow the Nigerian Approved Standards on Auditing in the conduct of their audits. The "approved accounting standards" are those standards that are issued or approved by the Nigerian Accounting Standards Board (NASB). The compliance with the Statements of Accounting Standards (SAS) issued by the Board is statutorily mandated by CAMA, 1990.

\section{METHODOLOGY}

Survey research design was used in this study. This design is considered suitable because of its ability to view comprehensively the major questions raised in the study. Survey research design is described by Denscombe (2003) as an efficient way of collecting information from a large number of respondents and the ability to use statistical techniques to determine statistical significance. The population of the study comprised all auditors, auditees (private accountants and management) and audit beneficiaries (stockbrokers and investors) in Nigeria.

The purposive sampling technique was employed in this study. A sample consisting of respondents in Lagos State was considered a good representation of the respondent groups since the ultimate test of a sample design is how well it represents the characteristics of the population it purports to represent (Emory and Cooper, 2003). A sample size of forty (40) is targeted for each respondent groups. The choice of this sample size is guided by literature on the maximum and minimum practical sample size of not less than thirty (30) subjects per group category for any statistical test (Balian, 1994; Denscombe, 2003). The primary data was obtained from the target respondents through a carefully constructed questionnaire. The questionnaire was designed to capture the demographic data of respondents and their opinion with respect to the research questions. The questionnaire was divided into two (2) sections. Section A was designed to obtain information on the demographic and subject details of respondents, while section B consisted of questions measuring the perception of respondent groups on audit expectation gap in Nigeria. The questionnaire was constructed using a five-point Likert type scale. The respondents were required to indicate the extent of their agreement or disagreement with each of the statements on a score of one (1) to five (5). A score of one (1) represented strong disagreement with the statement, while a score of five (5) represented strong agreements. This type of scaling was suggested when items are to be judged on a single dimension and arrayed on a scale with equal interval (Alreck and Settle, 1995). The data collected were analyzed using both descriptive and inferential statistics. The descriptive method described the demography of respondents using percentages. The hypotheses formulated for the study were tested using analysis of variance (ANOVA). Analyses were carried out with the aid of the Statistical Package for Social Sciences, (SPSS Version 15.0).

\section{DATA ANALYSIS AND INTERPRETATION OF RESULTS}

Respondents were grouped into five; external auditors, stock brokers, investors, private accountants and management. Out of the two hundred (200) copies of questionnaire administered, a total of one hundred and sixty two (162) copies were returned and used for analysis. This represents an overall response rate of eightyone per cent $(81 \%)$ for all the groups. These responses were used in providing answers to the questions raised in the study. Table 1 presents information on the responses of each group of respondents.

\section{Test of research hypotheses}

$\mathrm{H}_{1}$ : There is no significant difference in the perception of respondent groups on the existence of audit expectation gap in Nigeria.

For the purpose of this analysis, the respondents consisted of five (5) groups. $\mathrm{H}_{1}$ concerned the existence of audit expectation gap in Nigeria. Two (2) items from the questionnaire (statements 1 and 8 ) are associated with this hypothesis. The result of the hypothesis proposed is shown in Table 2. The two statements used in validating the proposition made on the existence of audit expectation gap have a high F-ratio of above 5.00 with p-value less than 0.05 . Consequently, the conclusion was that there are significant differences in the perceptions of respondent groups on the existence of audit expectation gap in Nigeria.

$\mathrm{H}_{2}$ : There is no significant difference in the perceptions of respondent groups on the existing duties and responsibilities of auditors in Nigeria.

The second hypothesis proposed for this study concerned respondents' view on the existing duties and responsibilities of auditors. This hypothesis was tested using statements 2 and 7 in the questionnaire. The result of the hypothesis proposed is shown in Table 3 . The two statements used in validating the proposition made on the existing duties and responsibilities of auditors have Fratios of 5.325 and 4.616 respectively with $p$-value less than 0.05 . Therefore, it was concluded that there is significant difference in the perception of respondent groups on the existing duties and responsibilities of auditors in Nigeria.

$\mathrm{H}_{3}$ : There is no significant difference in the perception of respondent groups on the usefulness of audit report for investment decision.

The third hypothesis proposed for this study concerned respondents' perception on the usefulness of audit report in making investment decisions. The hypothesis was tested using statements 3 and 5 in the questionnaire. The result of the hypothesis proposed is shown in Table 4. The two statements used in validating the proposition made on the existing duties and responsibilities of auditors have high F-ratio of above 5.00 and with p-value less than 0.05 . Therefore, it was concluded that there is 
Table 1. Questionnaire distribution and responses.

\begin{tabular}{lccc}
\hline Respondent group & Number of survey & Number of responses & \% of responses \\
\hline External auditors & 40 & 36 & 90.0 \\
Stock brokers & 40 & 28 & 70.0 \\
Investors & 40 & 38 & 95.0 \\
Private accountants & 40 & 38 & 95.0 \\
Management & 40 & 22 & 55.0 \\
Total & 200 & 162 & 81.0 \\
\hline
\end{tabular}

Source: Analysis of survey data (2011).

Table 2. Results of ANOVA on the existence of audit expectation gap in Nigeria.

\begin{tabular}{|c|c|c|c|c|c|c|}
\hline Statement & & Sum of squares & df & Mean square & $\mathbf{F}$ & Sig. \\
\hline \multirow{3}{*}{$\begin{array}{l}\text { The messages communicated by audit } \\
\text { reports are different from what the public } \\
\text { expect of auditors }\end{array}$} & Between groups & 52.544 & 4 & 13.136 & \multirow[t]{3}{*}{5.860} & \multirow[t]{3}{*}{$0.000^{*}$} \\
\hline & Within groups & 351.932 & 157 & 2.242 & & \\
\hline & Total & 404.475 & 161 & & & \\
\hline \multirow{3}{*}{$\begin{array}{l}\text { Audit expectation arises from a combination } \\
\text { of excessive expectations and insufficient } \\
\text { performance }\end{array}$} & Between groups & 55.764 & 4 & 13.941 & \multirow[t]{3}{*}{9.278} & \multirow[t]{3}{*}{$0.000^{*}$} \\
\hline & Within groups & 235.896 & 157 & 1.503 & & \\
\hline & Total & 291.660 & 161 & & & \\
\hline
\end{tabular}

*significant at 0.05; source: Analysis of survey data (2011).

Table 3. Results of ANOVA on the existing duties and responsibilities of auditors.

\begin{tabular}{|c|c|c|c|c|c|c|}
\hline Statement & & Sum of squares & df & Mean square & $\mathbf{F}$ & Sig. \\
\hline \multirow{3}{*}{$\begin{array}{l}\text { The existing duties and responsibilities of } \\
\text { auditors are adequate and clearly } \\
\text { defined. }\end{array}$} & Between groups & 55.314 & 4 & 13.829 & \multirow[t]{3}{*}{5.325} & \multirow{3}{*}{$0.000^{*}$} \\
\hline & Within groups & 407.680 & 157 & 2.597 & & \\
\hline & Total & 462.994 & 161 & & & \\
\hline \multirow{3}{*}{$\begin{array}{l}\text { Auditors' responsibilities need to be } \\
\text { increased particularly in fraud } \\
\text { detection. }\end{array}$} & Between groups & 18.259 & 4 & 4.565 & \multirow[t]{3}{*}{4.616} & \multirow[t]{3}{*}{$0.002^{*}$} \\
\hline & Within groups & 155.272 & 157 & 0.989 & & \\
\hline & Total & 173.531 & 161 & & & \\
\hline
\end{tabular}

*significant at 0.05; source: Analysis of survey data (2011).

Table 4. Results of ANOVA on the usefulness of audit reports for investment decisions.

\begin{tabular}{|c|c|c|c|c|c|c|}
\hline Statement & & Sum of squares & df & Mean square & $\mathbf{F}$ & Sig. \\
\hline \multirow{2}{*}{$\begin{array}{l}\text { Users rely on audited financial } \\
\text { statement for investment decisions }\end{array}$} & Between groups & 55.088 & 4 & 13.772 & 6.398 & $0.000^{*}$ \\
\hline & Within groups & 337.925 & 157 & 2.152 & & \\
\hline \multirow{2}{*}{$\begin{array}{l}\text { The audit report should be expanded } \\
\text { to be more useful and } \\
\text { understandable so as to make } \\
\text { informed decisions }\end{array}$} & Between groups & 23.663 & 4 & 5.916 & 5.074 & $0.001^{*}$ \\
\hline & Within groups & 183.034 & 157 & 1.166 & & \\
\hline
\end{tabular}

*significant at 0.05 ; source: Analysis of survey data (2011).

significant difference in the perception of respondent groups on the usefulness of audit report for investment decision.

\section{CONCLUSION AND RECOMMENDATIONS}

The audit expectation gap has been the subject of many 
research projects in other developed countries like the U.S (Frank et al., 2001), the U.K (Innes et al., 1997), Australia (Gay et al., 1997), Denmark (Hojskov, 1998), New Zealand (Porter, 1993), and Singapore (Best et al., 2001). The concept of an audit expectation gap suggests that the public expects auditors to act in ways which are different from what auditors themselves would expect to act, in other words, the role senders are dissatisfied with the information from audit reports. The increase in litigation against and criticism of the auditor has left little room for doubt that the auditors are facing a liability and credibility crisis. (Russell 1986). Lim (1993) and Woolf (1985) assert that the blame should not be placed on the auditors totally as the nature and objectives of auditing are perceived differently among the auditors, auditees and audit beneficiaries. These differences in perception caused the existence of the audit expectation gap.

This study empirically examines the existence of expectation gap in Nigeria by evaluating the perceptions of auditors, auditees (accountants and management) and audit beneficiaries (stockbrokers and investors). It also considers respondents' perception on the existing duties and responsibilities of auditors. In addition, the study explores respondents' perception of the quality and usefulness of the auditors' report which reflects the effectiveness of an auditors' report as a communication medium between auditors and users.

Respondents were grouped into five, external auditors, stock brokers, investors, private accountants and management. Out of the two hundred (200) copies of questionnaire administered, a total of one hundred and sixty two (162) copies were returned and used for analysis. This represents an overall response rate of eighty-one per cent $(81 \%)$ for all the groups. The survey conducted clearly shows, that audit expectation gap exists in Nigeria. Respondents were also of the opinion that the existing duties and responsibilities of auditors are not clearly defined and are inadequate. Their responses also revealed that auditors' duties and responsibilities should be expanded to make it more useful to investors. In addition, evidence exists that respondent groups rely on audited financial statement in order to make informed decisions. The expectation gap was found to be wide particularly on the issues of the auditors' responsibilities on fraud detection as significant number of the respondents believed that auditors' responsibilities should be widened in this regard.

The study provides evidence about the nature of an audit expectation gap between auditors and users. The propositions made in the study were evaluated using selected items or statements from the questionnaire. The results of the first hypothesis reveal that there was significant difference in the perception of respondent groups regarding the existence of audit expectation gap in Nigeria.

The study also hypothesized that there is no significant difference in the perception of respondent groups on the existing duties and responsibilities of auditors in Nigeria.
The two statements used were significant with p-value < 0.05. The conclusion drawn from the findings was that there is significant difference in the perceptions of respondent groups on the existing duties and responsibilities of auditors in Nigeria. Similarly, results from the analysis carried out on $\mathrm{H}_{3}$ also reveal that there is significant difference in the perception of respondent groups on the usefulness of audit report for investment decision. In the light of the research findings, the following recommendations are made:

i. The existing duties and responsibilities of auditors should be clearly defined and widened to include fraud detection.

ii. The public (users of financial statements) should be educated about the objects of an audit, auditors' role and responsibilities.

iii. Quality control in audit firms should be implemented to ensure quality performance of the auditors thereby ensuring investors' confidence.

\section{Suggestions for further study}

In view of the fact that the respondents of this study are based in Lagos, another study that will cover major cities in Nigeria is suggested. It is also suggested that future researchers should select larger respondent groups so as to enhance the credibility of the research findings when drawing inferences about the population. It may be interesting to find out if demographic factors such as sex, age, working experience and accounting qualification do influence the perception of an audit expectation gap among different sample groups.

\section{REFERENCES}

Alreck PL, Settle RB (1995). The Survey Research Handbook. ( $2^{\text {nd }}$ ed.). Chicago: Richard D. Irwin Inc.

Balian ES (1994). The Graduate Research Guidebook: A practical approach to doctoral/masters research. Maryland: University Press of America.

Beck GW (1974). Pubic Accountants in Australia -Their Social Role, Melbourne: Australian Accounting Research Foundation.

Beelde DI, Cooper S, Leydens H (2005). Expectations of users Of Financial Information With Regard To The task Carried Out By Auditor. http://www.Feb.ugent.be/fac/research/WP/Paper/WP_99_75. pdf-22No2005.

Benau MAG, Humphrey C, Moizer P, Turley S (1993). Auditing Expectations and Performance in Spain and Britain: A Comparative Analysis, Int. J. Account., 28: 281-307.

Best PJ, Buckby S, Tan C (2001). Evidence of the Expectation Gap in Singapore, Manage. Audit. J., 16(3): 134-144.

Boonyanet C, Ongthammakul S (2006). Expectation gap in Thai accounting society: changes and comparison of its neighbours. Paper presented at the Asian Pacific Conference on International Accounting Issues. Hawaii, USA, pp. 15-18.

Corporate Governance Code of Nigeria. (2005). Lagos: SEC Companies and Allied Matters Act (1990) Lagos: Nigeria.

Davidson L (1975). The Role and Responsibilities of the auditor: perspective, expectations and analysis. Unpublished Background Paper for the Commission on Auditors' Responsibilities.

Denscombe M (2003). The good research guide for small-scale social 
research projects. ( $2^{\text {nd }}$ ed.), Maidenhead-Philadelphia: Open University Press.

Dixon R, Woodhead AD, Soliman M (2006). An investigation of the expectation gap in Egypt. Manage. Audit. J., 21(3): 293-302.

Emory CW, Cooper DR (2003). Business Research Methods $\left(6^{\text {th }}\right.$ edition), Illinois: Richard D. Irwin Inc.

Epstein M, Geiger M (1994). Investor views of audit assurance: Recent evidence of the expectation gap. J. Account. 177(1): 60-66.

Gay G, Schelluch P, Reid I (1997). Users' Perceptions of the Auditing Responsibilities for the Prevention, Detection and Reporting of Fraud, Other Illegal Acts and Error. Aust. Account. Rev., 7(13): 51-61.

Godsell D (1992). Legal liability and the audit expectation gap. Singapore Account., 8: 25-28.

Hojskov L (1998). The Expectation Gap between Users' and Auditors' Materiality Judgements in Denmark, paper presented at the Second Asian Pacific Interdisciplinary Research in Accounting Conference 46 August, Japan.

Humphrey CG, Moizer P, Turley WS (1993). The audit expectation gap in Britain: An empirical investigation. Account. Bus. Res., 23: 395411.

Jennings M, Reckers MJ, Kneer DC (1993). The significance of audit decision aids and precase jurists' attitudes on perceptions of audit firm culpability and liability". Contemp. Account. Res., 9: 489-507.

Koh KH, Woo ES (1998). The expectation gap in auditing. Manage. Aud. J., 13(3):147-154.

Lee TA (1970). The nature of auditing and its objectives, Accountancy, 81: 292-296.

Lee T, Palaniappan A (2006). Audit Expectation Gap: An Empirical Study in Malaysia, paper presented in The Malaysian Finance Association's 8th Annual Conference at University Malaysia Sabah, Kota Kinabalu.

Lee TH, Gleock JD, Palaniappan AK (2007). The Audit Expectation Gap: An empirical study in Malaysia. South Afr. J. Account. Aud. Res., 7: $1-15$

Lee TH, Md Ali A, Gleock JD, Yap CS, Ng YL, Boonyanet W (2010). The Audit Expectation Gap in Thailand. South Afr. J. Account. Audit. Res., 10: 1-17

Low AM (1980). The auditor's detection responsibility: is there an 'expectation gap'?. J. Account., 150(10): 65-70.
Lowe DJ (1994). The expectation gap in the legal system: perception differences between auditors and judges. J. App. Bus. Res., 10: 3944.

Liggio C (1974). The expectation gap: the accountant's Waterloo. J. Contemp. Bus., 3: 27-44.

Maccarrone $E$ (1993). Using the expectation gap to close the legal gap. CPA J. 63: 10-16.

Mc Enroe JE, Martens SC (2001). Auditor's And Investor's Perception of the Expectation Gap. Account. Horiz., 15(4): 345-358.

Mohamed S, Muhamad-Sori Z (2002). Audit Expectation Gap - The Malasian Experience, Chartered Secretary Malaysia, January, pp. 12-15.

Monroe GS, Woodliff DR (1993). The effect of education on the audit expectation gap. Account. Financ., 33(5): 61-78.

Murphy P, Maynard ML (1996). Using Judgment Profiles to Compare Advertising Agencies' and Clients' Campaign Values. J. Advert. Res., 36 (2): 19-27.

Porter B (1993). An empirical study of the audit expectationperformance gap. Account. Bus. Res., 24: 49-68.

Porter B, Gowthorpe C (2004). Audit expectation-performance gap in the United Kingdom in 1999 and comparison with the gap in New Zealand in 1989 and in 1999. The Institute of Chartered Accountants of Scotland Edinburgh.

Reiter SA, Williams PF (2000). The History and Rhetoric of Auditor Independence Concepts, Binghamton University. http://lesl.man.ac.uk/ipa/papers/44.pdf.

Salehi M (2007). An empirical study of corporate audit expectation gap in Unpublished $\mathrm{PhD}$ thesis, University of Mysore.

Sikka P, Puxty A, Willmott H, Cooper C (1998). The Impossibility of Eliminating the Expectation Gap: Some Theory and Evidence. Crit. Perspect. Account., 9(3): 299-330.

SPSS 15 for Windows Evaluation Version Release, 15.0 (2006)

Trauth EM, Farwell DW, Lee D (1993). The IS Expectation Gap: Industry Expectations Versus Academic Preparation. MIS Q., 17(3): 47-72.

Woolf E (1985). We Must Stern the Tide of Litigation, Accountant, pp. 18-19. 